\title{
"Being Bilingual Means Being a Foreigner". Categorizing Linguistic Diversity among Students in Danish Higher Education ${ }^{1}$
}

\begin{abstract}
One of the effects of the internationalization of Danish higher education is a more mobile and linguistically heterogeneous student population aiming at both the national and international labor market. At the same time efforts to increase participation in higher education among domestic students have resulted in a more diverse student body in terms of social and ethnic background. To some extent the two groups of students overlap, but they are treated very differently by the university administration. Whereas students with international experience are counted and categorized as such, and are offered language courses before going abroad or when arriving in Denmark, minority students are either part of the mainstream or identified as in need of remedial courses. The latter does not correspond very well with the general shift towards more learner-centered approaches in higher education, which potentially opens up to a resource perspective on multilingual students' language background. The present paper is a literature review focusing on the various labels used when categorizing students according to their linguistic background. The purpose of this is to raise awareness about labelling as a sensitive issue and to propose a multilingual pedagogical framework for students to benefit from their full language potential during their academic studies.
\end{abstract}

Keywords: linguistic diversity, labelling, minority students, multilingualism

\section{Introduction}

When Katja Årosin Laursen interviewed students at the School of Pharmaceutical Sciences at University of Copenhagen about language issues, one student with Arabic background responded that to her the label bilingual means "a person who knows two languages. But here [in the university context] it is taken as if you are a foreigner. So being bilingual means being a foreigner" (Laursen 2013: 42-43, my translation). The student added that university staff prefers to use the term "student with Danish as a second language" to avoid the allegedly negative connotations of alternative labels: 'second generation immigrant', 'foreigner' and 'bilingual'. The student exemplified both how sensitive labeling of student categories is and how linguistic labels are being conflated with social and ethnic labels. Both issues have been discussed extensively in studies on higher education in English-speaking countries (e.g. Spack 1997, Garcia 2009, Hafernik/Wiant 2012, Preece 2011), and have also been raised as an issue in studies of national language policies in primary school in the Nordic countries (e.g. Kristjansdóttir 2011, Sickinghe 2013). However, there has been very little focus on linguistic diversity in general among students in Danish higher education, despite the fact that there is a growing concern with the role of languages in the ongoing internationalization of universities as well as in the transformation of universities from elite institutions to centers of mass education (Gregersen 2012, Tange 2012, Hultgren 2014).

1 I would like to express my gratitude to the two anonymous reviewers who added valuable input on both the content and the structure of this paper.

\footnotetext{
* Anne Holmen

Department of English, Germanic and Romance Studies

The Faculty of Humanities

University of Copenhagen

Njalsgade 128-130

DK-2300 Copenhagen $S$

aholmen@hum.ku.dk
} 
The present paper is a literature review focusing on the various labels used when categorizing students according to their linguistic background. It is motivated by what seems to be a blind spot in the development of teaching and learning activities in Danish higher education. On the one hand, study programs seem more engaged in developing student-centered and individualized learning activities than earlier (e.g. Ingerslev et al. 2013); on the other hand, programs seldom include the actual linguistic background of students, and even when ascribing to European goals of plurilingualism for students this mainly concerns the balance between English and Danish (Extra/Yagmur 2012). Apparently, this leaves very little room for acknowledging other languages as learning resources and for developing teaching practices which view all students as e.g. 'multilingual subjects' (Kramsch 2009). Instead other languages than Danish and English are either ignored or experienced as features of foreignness and thus of non-belonging as expressed by the student in Laursen's study. This observation is supported by Daryai-Hansen's empirical study on dominant discourses on languages in Denmark; in documents on education and schooling she finds a consistent four-step language hierarchy with Danish at the top, followed by English, then an unspecified group of other "relevant foreign languages" (including the other Scandinavian languages) and at the bottom immigrant and minority languages, hardly ever called by their name (Daryai-Hansen 2010). As the paper will show, this language atmosphere seems to affect the minority students' identity as speakers of Danish as a second language and not only as speakers of minority languages, and it is underlined that careful labeling is crucial in the universities' development of language policies for a more diverse student body.

\section{Contexts of linguistic diversity in higher education}

Before looking into patterns of labeling students according to languages, I approach the question through three sets of contextual development which according to the literature covered here have an impact on our current way of thinking about languages in higher education: the first is internationalization of universities which draws our attention to the choice of Danish versus English on the one hand and English versus other foreign languages on the other hand; the second context concerns the wider access to higher education in Denmark and, as a consequence, the emergence of more language minority students in university classrooms, and the third context introduces what appears to be a new educational paradigm of multilingualism and translanguaging. This more normative context is helpful in shifting the focus from the traditional and often highly regulated domains of language use at universities (i.e. the languages of instruction, of research, of administration and of external communication plus languages taught as subjects) into the less frequently studied field of languages involved in students' learning and communication practices. These students may be seen as multilingual because they draw on more than one language in their everyday interactions, in and out of classrooms, engaged in curricular activities or on social media (Canagarajah 2011). In this paper, the concept of multilingualism will mainly refer to individual and group language use, and it will apply to language users irrespective of their language background, their level of proficiency in the languages involved or their ways of integrating languages (in separating languages, translating between them, code-mixing, crossing, or polylanguaging, Blommaert/Rampton 2011). The concept will also apply to language policy at institutional or societal level in so far as this aims at promoting the use of more than one language in a given social context.

\subsection{Internationalization of universities and higher education: English and other foreign languages}

During the last 10 years Danish universities have been through major changes due to global cooperation and marketization of education and the knowledge economy (Boden/Wright 2010, Mortensen/Haberland 2012). The changes are part of a wider transformation of universities and higher education, mainly driven by universities in Anglophone countries who are operating on 
a "Global Higher Education Stage" based on increased transnational mobility among staff, students, programs and institutions (Preece 2011). Although from a fairly marginal position, Danish universities see themselves as players at this global stage, where market forces have changed the institution from being predominantly national to being what Mortensen/Haberland (2012) refer to as "post-national" (or international). All Danish universities are still publicly funded, provide free tuition and are regulated by rules and regulations set out by the Danish government; however, an increasing part of research funding is now based on external sources, often acquired in cooperation with other European or Nordic partners. When competing for funding and for other branding purposes, universities explicitly draw on their strategic alliances with other universities and on professional networks among researchers. International experience is now seen as an asset in educating new researchers through $\mathrm{PhD}$ programs, and research publication practices are dominated by English. Many research positions are advertised internationally and the number of faculty members with an international background has been growing gradually, now making up almost $20 \%$ of all newly recruited researchers (Hultgren 2014). Student mobility is encouraged, both in the shape of study exchange programs and as full degree students, but also through internships in companies, organizations, embassies etc. located outside Denmark. This means more students with international experience taking part in teaching and learning activities in the Danish context. Some of these have a Danish background to compare with their international experience whereas others are new to education in Denmark, but bring in a variety of educational experiences and expectations. The composition of students has brought about an increased focus on the multicultural or the international classroom ${ }^{2}$, and on different learning styles and preferences, but so far very little concern about the role of languages involved, except for the balance between Danish and English medium instruction.

However, internationalization of higher education has not only brought about a more diverse staff and student population at Danish universities in terms of numbers, but also in terms of languages used. In her study on international staff at University of Copenhagen, Merike Jürna (2014) found that 35 different languages were used by her 150 informants, and that 26 of these reported to have English as their first language. All 150 used English in their daily work life at the university and 48 also Danish. No studies have ever been carried out of student language repertories at University of Copenhagen (but one study at Roskilde University, Haberland/Risager 2008). Since 1990s, the all-Danish language practice directed to students has been supplemented with the use of English for instruction, exams and administrative communication at all Danish universities (Hultgren 2013). This is mainly motivated by a wish to attract international full degree students, but also to provide teaching for exchange students and to prepare domestic students for the international labor market. At the same time there is a widespread concern that Danish will gradually lose ground as an academic and professional language. This calls for what is often referred to as a parallel language strategy. "Parallellingualism" or "parallel language use" was introduced in Nordic language policy debates around 2000 and included in the Nordic Language Declaration in 2006. It refers to the concurrent use of two or more languages in a situation where none of the languages abolish or replace each other ${ }^{3}$. In particular, the term refers to the parallel use of English and one of the Nordic majority languages, across social domains and institutions, including universities. Parallel language use may take many forms from complete to partial use, depending on context, target group and legal status of a given communicative practice (Gregersen ed. 2014). One recent example of the way in which the parallel language strategy is implemented vis-à-vis students is the decision at faculty of Science at University of Copenhagen to teach all MA courses through English and all BA courses through Danish. Other faculties at the university have de-

2 Four Danish universities take part in an Erasmus project 2012-2015 led by Aarhus University on "Multilingual and Multicultural Learning Spaces", see http://intluni.eu/about-intluni/

3 Despite certain theoretical weaknesses (e.g. Preisler 2010) and lack of systematic knowledge about its implementation in practice, the term parallel language use has provided a useful platform for discussing language policy in Nordic higher education, see e.g. the thematic issue of the journal Nordand (2012) and the recent comprehensive volume edited by Gregersen (2014). 
veloped similar practices, e.g. by identifying specific programs taught through English for both domestic and international students, but otherwise leaving the language choice to each individual teacher and sometimes to groups of students.

The parallel language strategy focuses on the balance between Danish and English. However, Roskilde and Copenhagen University have decided to experiment with the use of other languages than Danish and English for non-language students inspired by the recommendations to promote plurilingual competencies through education put forward by both the European Union and the Council of Europe (overview in Extra/Yagmur 2012). The idea behind the French and German Language Profiles at Roskilde University and the strategy of More Languages for More Students at University of Copenhagen is to improve language skills of students across the universities through developing new forms of content-and-language-integrated-learning, academic literacy in a foreign language or language courses preparing students for field work or study periods abroad. Both the parallel language strategy of Danish and English and the inclusion of a wider repertoire of foreign languages mark the break away from the ideology of monolingualism at Danish universities which had been dominant since the establishment of the university as a national institution during the $19^{\text {th }}$ century (but not during earlier periods, Gregersen 2012). According to one definition, monolingual universities assume that the language used for instruction is also the students' first language and the language used during their secondary education and in the labor market they target (van Leeuwen 2004). It is obvious that this assumption does not hold any longer in practice.

To sum up, internationalization of universities and higher education has affected the composition of students in Danish university classrooms through an increasing number of students with international experience. This has produced a more heterogeneous student body in terms of language background. It has also meant a change of language policy towards a parallel strategy between Danish and English medium instruction (including exams and administrative communication with students) and towards attempts to reintroduce more foreign languages into general education.

\subsection{Wider access to higher education: Minority students and Danish}

For a decade, it has been one of the major goals of Danish educational policy to ensure that $25 \%$ of an age group completes higher education. This has meant opening up to wider groups of students, motivated by issues of social justice as well as the needs of the industry and the policy of growth embedded in neoliberal economy (see e.g. Denmark 2020. Knowledge, growth, wealth, welfare). However, during 2013 there has been a growing political concern with the quality and efficiency of the present system. Consequently, the Danish government has appointed a committee (Committee for quality and relevance of higher education) to come up with analyses of the economy and outcome of higher education. In the committee's first report it is argued that the development from elite to mass education has gone too far and there is a concern that wider participation will not cost-efficiently produce the highly-skilled workforce the country needs to secure its social welfare in the knowledge economy. As a consequence, a number of structural changes have been proposed including restricted intake and closing down study programs. The ensuing discussion has revealed fundamental differences in what produces educational quality: external regulation or internal reform (e.g. in terms of developing curriculum and the teaching and learning environment) (see, e.g., Magisterbladet 4, 2014).

It is obvious that the access agenda has already been influential in changing the student body both in terms of numbers and student backgrounds. This means that today Danish universities include more domestic students without the traditional academic background in their families, including bilingual or multilingual students from minority groups. These will be referred to as minority students in the present paper (see discussion of terminology preceding table 1 in section 3 below). To include these students in academic learning activities is a new challenge for higher education; to succeed in this, it is crucial to know more about their needs, expectations and academic aspirations (Ingerslev et al. 2013). 
Language minority students are of particular interest for the purpose of the present paper. However, very little information is available about them, their educational situation and their share of a year group of students. There are several reasons for this. Minority students do not form an official category within higher education, there are no quotas, and no statistical information available on their access to or completion of higher education. From interviews with student councilors we know that there is awareness about their participation, but also a widespread hesitancy among Danish university administrators in identifying minority students as distinct from majority students (Rektorkollegiet 2001, Lund/Berthelsen 2008, Laursen 2013). One study, by Hoff/Demirtas (2009), focuses on minority students' reasons for dropping out from their university studies in comparison with a comparable group of students who continue their studies. Like most other students, the minority students who have dropped out give reasons related to both content and teaching practices in the field of study and a mixture of personal economy and family background. However, one result puzzles the authors: the risk of dropping out is considerably higher among domestic minority students, i.e. students with Danish citizenship and a Danish entrance exam, compared to minority students with foreign citizenship and a foreign entrance exam. Among the last group are refugees, spouses of Danish citizens and EU-citizens who have moved to Denmark after secondary school and sometimes after starting an academic study in another country. The domestic minority students who drop out either do this because they resemble their majority peers in 'zapping' between different study programs (this is suggested by the authors) or their academic development is hampered by a mixture of language and social problems, either experienced during their university studies (as suggested by Rektorkollegiet 2001) or following them from previous schooling (as suggested by Petersen 2006). Unfortunately, Hoff/Demirtas' study does not include language issues among the options which the students can choose from when giving reasons for dropping out. Therefore this study does not provide us with insight into how to unravel the role of languages against other factors.

However, from Danish studies of lower- and upper secondary education we know that minority students in general underachieve in school (Elsborg et al. 2005, Danish Evaluation Institute 2006), and that explaining this is a complex issue. PISA-studies point to the students' cultural and linguistic family background (Christensen et al. 2014) whereas Allerup (2004) concludes that the difference between majority and minority students in average grades in school leaving exams cannot be explained by socio-economic differences exclusively. He suggests that the students' minority status also plays a role, but does not consider whether the lower grades are caused by the students' insufficient mastery of academic Danish or by lack of appropriate school measures to deal with this diversity. It may also be a combination of factors influencing their educational success (see e.g., Holmen 2009). Some of the Danish minority students presumably fit the following characteristics of what is frequently referred to in the US as "Generation 1.5 students", i.e. minority students who metaphorically fall between the first generation of migrants and following generations who have to a wider extent adjusted to education in the US:

\footnotetext{
Even though Gen 1.5 students indicate they speak a language other than English at home, they may use English extensively to communicate outside the family. Gen 1.5 students may not be completely fluent or literate in the language used in the home (variously called the Mother Tongue, Heritage Language, Home Language, First Language or Native Language), having been educated mostly in US schools. Harklau et al. (1999) note that although they speak English at school, their academic skills may be weak. They often do not self-identify with either international students or native English speakers, another instance of feeling "inbetween-ness". Many Gen 1.5. students have had interrupted educations due to their family situations and may have had no ESL instruction from qualified ESL instructors (Hafernik/Wiant 2012: 12).
}

Most likely, Danish minority students make up a mixed group of, on the one hand, students with strong academic skills, well-educated parents and a privileged background in another country, on the other hand, newcomers in academia, presumably less fortunately equipped with relevant educational and cultural capital. This is bound to make a difference for their transition into higher education. However, despite socio-economic differences they may also share a cultural identity 
of being affiliated with another language than Danish (and English) during their childhood and of being partly identified by others as speakers of that language or of being multilingual. Often they are also identified as second language speakers of Danish and - as we shall see later - met with first language norms which over time may produce silent students and students with low selfesteem. To sum up, wider participation in higher education has brought forward a focus on the need for underprivileged students to break the academic code in order to get access to curriculum and relevant learning processes (Maton 2004). For many language minority students this is both a matter of grasping a specific register - a condition which they share with other students from a non-academic background - and developing their second language to a higher level.

\subsection{A new educational paradigm of multilingualism: Translanguaging}

Three of the key words at the annual conference of the American Association of Applied Linguistics in 2014 were multilingualism, plurilingualism and translanguaging. They frequently appeared in plenary addresses and in a number of titles of colloquia and panels on language development, language teaching, language assessment and language policy related to all levels of the educational system, including higher education. Plurilingualism was also the theme for the annual seminar on "TESOL at AAAL" following up on a recent volume of TESOL Quarterly. The three key words were often referred to as part of a new paradigm for applied linguistics, developing education in its own right, but also influencing second language acquisition and testing practices, and drawing on Garcia (2009), Canagarajah (2011), Blackledge/Creese (2010), and Shohamy (2006) among others. Van der Walt (2013: 18-19) has observed the same change of direction within African and European applied linguistics and concludes her book on higher education with a chapter called "From Mono to Multi. New Thinking about Higher Education". She refers to Jessner (2008: 18) when claiming that in Europe "this is a direct result of the European Union's commitment to multilingualism".

Danish universities are also being influenced by the international development and by the multilingual language policy of the European Union and the Council of Europe. They all target an increase in student mobility, both outgoing and ingoing and including exchange students as well as full degree students. In addition, the Danish government stresses the need to focus not only on student mobility to produce internationalization, but also on drawing on the intercultural, linguistic and academic resources already present in the university sites through staff and students thus creating an international learning environment as part of what is referred to as "internationalization at home" (Enhanced Insight through Global Outlook 2013:19). However, it seems that the universities' orientation towards multilingualism mainly concerns the balance between Danish and English, only rarely includes other languages and in those cases a very limited number of foreign languages (see the language hierarchy described by Daryai-Hansen 2010). This was also apparent in a recent survey on Trends in policies and practices for multilingualism in Europe carried out by Extra/Yagmur (2012). Out of 65 participating universities, three were Danish. They responded positively to questions about student mobility, use of two languages for instruction and, to a certain extent, whether languages were offered to non-language students. They responded negatively to two other questions. One concerns the provision of additional support in the national language, which at some of the 65 universities is offered only to international students and at other universities to all students irrespective of their background. At Danish universities this language need is left to general education (pre-university) or, in case of Danish as a second language, to adult education outside university auspices (DMA Research 2005). The other issue concerns the role of minority languages. In the recommendations of the survey, the editors refer to these as "the gold mine of immigrant languages" and as valuable linguistic capital at a time when "an ever wider range of language skills is needed". In line with this, 33 out of 65 universities report that they make a conscious effort to recruit not only international students, but also domestic students with minority background. No such effort has ever been reported at a Danish university. The survey shows that the language policy at Danish universities is concerned with the balance 
between Danish and English, but does not include the two areas specifically related to minority students. This impression is confirmed in Hultberg's overview of language policies across Danish universities (2014).

Neither does the new paradigm of translanguaging as a pedagogical approach ${ }^{4}$ so far seem to have made an impact into Danish higher education - although it has been discussed theoretically and in relation to students in primary school (Jørgensen 2008) - and although it is fundamentally in line with dominant ways of thinking about academic learning as student-centered and facilitated by dialogue across relevant contexts (Ingerslev et al. 2013). Garcia defines translanguaging from the perspective of the users as "multiple discursive practices in which bilinguals engage in order to make sense of their bilingual worlds" (2009: 45). Their languages are not used as discrete and separated, but make up a repertoire emerging out of local practices for communicative purposes. Canagarajah calls it "a naturally occurring phenomenon" among multilingual students, often developed "surreptitiously behind the backs of the teachers in classes which proscribe language mixing" (2011: 8). He sees this as a resource perspective on the students' language background and a potential for developing new teaching and learning activities; in his case, translanguaging is being used as a fruitful instrument in developing a more relevant academic writing course for a diverse group of students (including majority students). However, he also cautions against a too romanticized view on the scope of bringing translanguaging into higher education. He argues that it is important to find a balance between the inherent and often functionally motivated normativity of academic discourse and any student-centered approach to learning, and to develop both teaching and assessment practices accordingly. To introduce an explicit multilingual teaching and learning approach in one shape or another into Danish higher education will change the learning environment through new practices and a redefinition of language norms, but also through a shift in perspective from language-as-problem to language-as-resource (Ruiz 1984). This might eventually also lead to changes in labeling of students (see the title of this paper).

\section{Categories of students at Danish universities - different degrees of being multilingual?}

Few studies on linguistic diversity in Danish higher education focus on the actual language composition in classrooms or on linguistic practices of a mixed student body (Pedersen 2006, Laursen 2013, Odgaard 2014). Instead there is a focus on numbers, especially concerning transnational student mobility, and on educational problems for students with a minority background. International students are identified through their background for entering a Danish institution (through their way of applying), and divided into a fee-paying and a non-fee-paying group according to nationality ${ }^{5}$. A substantial proportion of the international students come from one of the other Nordic countries and Nordic self-governing areas (Faroe Islands, Greenland, Åland). This is a special group in relation to competence in Danish because they have often either learned some Danish as a foreign language in school (Hauksdottir 2012) or are familiar with Danish as a "neighbor language ${ }^{6 "}$. Some of the international students are 'free-movers' - a term used for students who organize their own study abroad. In addition, there are international students who apply through the

4 The term translanguaging was first developed to identify a bilingual pedagogical practice in Welsh schools where students alternated between English and Welsh when reading and writing. It was later applied as a multilingual approach to minority education in primary school (Garcia 2009, Blackledge/Creese 2010). Canagarajah has suggested transferring this approach to higher education (2011). Preece (2011) does not use the term, but talks of a similar approach to higher education when proposing that universities should be seen as "multilingual spaces" where pedagogical ways are developed which use "linguistic diversity as a bridge into academic studies and a resource in the design, delivery and assessment of the curriculum" (p. 141).

5 Students from the Nordic countries and self-governing areas and from the European Union and EØS-countries do not pay fees. Students with other backgrounds either get scholarships or pay fees.

6 "Neighbor language" is the Nordic term for the - in principle - mutually comprehensible Scandinavian languages. However, recent studies show that many young people do not see the other Scandinavian languages as immediately comprehensible (Delsing/Åkesson 2005). 
international offices and students on shorter exchange programs. Taken together, the two latter groups are sometimes referred to as "foreign students" (DMA Research 2005). The universities keep track of numerical changes within these groups (e.g. Mapping of educational internationalization, UCPH, 2012), but has no statistical information on Nordic students and free-movers.

Neither is there statistical information on the linguistic composition of other groups of students who have not applied as international students or exchange students. Some of these have Danish as their first or one of their first languages. For want of a better term, they are called majority students in this paper in order to distinguish them from minority students who are defined as students who do not include Danish among their first languages. Minority students have either learned Danish as a second language during primary and secondary education or they have supplemented their entrance exam from another country with specific courses of Academic Danish ("GIF" or classes leading to "Studieprøven"). Among the last group are refugees, spouses of Danish citizens and free-movers.

In the following overview different categories of students are organized according to their exposure to Danish and their entrance exam. It includes formal categories recognized by the universities as well as informal categories: exchange students and international full degree students, some of whom have a background in another Nordic country or self-governing area, as well as domestic minority and majority students with and without a Danish entrance exam. Taken together these make up the student body at Danish universities. However, they may all be seen as multilingual students, a term which in some studies only refer to non-majority students (e.g. Hafernik/ Wiant 2012). In his study of translanguaging practices as a teaching strategy for courses in academic writing, Canagarajah (2009) includes majority students in his target group. He adds that the contrast between 'multilingual' and 'monolingual' in the literature is too general and questions whether monolingualism is at all an ontological reality (see also Garcia 2009, Preece 2011). To pursue this line of thinking, majority students are included in the following overview of categories of multilingual students at Danish universities. Besides that, the overview is based on the two sets of formal criteria which are used in most studies about multilingual students at Danish universities, one being their command of Danish (or rather the context in which they were exposed to Danish) and the other their entrance exam.

\begin{tabular}{|l|l|l|}
\hline & $\begin{array}{l}\text { Domestic students with a Danish } \\
\text { entrance exam for the university }\end{array}$ & $\begin{array}{l}\text { International students with a } \\
\text { foreign entrance exam for the } \\
\text { university }\end{array}$ \\
\hline $\begin{array}{l}\text { Students exposed to Danish as } \\
\text { their first language (or one of } \\
\text { their first languages) }\end{array}$ & $\begin{array}{l}\text { Majority students, including } \\
\text { students from bilingual families }\end{array}$ & $\begin{array}{l}\text { Free movers and full degree } \\
\text { international students with Danish } \\
\text { family background }\end{array}$ \\
\hline $\begin{array}{l}\text { Students exposed to Danish as a } \\
\text { second, foreign or neighbor } \\
\text { language as part of their } \\
\text { primary or secondary education }\end{array}$ & Minority students & $\begin{array}{l}\text { Free movers, full degree students } \\
\text { and exchange students with a } \\
\text { Nordic background and/or previous } \\
\text { experience with Danish }\end{array}$ \\
\hline $\begin{array}{l}\text { Students exposed to Danish via } \\
\text { language classes after secondary } \\
\text { education }\end{array}$ & $\begin{array}{l}\text { Minority students who have } \\
\text { supplemented their foreign } \\
\text { entrance exam with the "GIF" } \\
\text { course }\end{array}$ & $\begin{array}{l}\text { Full degree and minority students } \\
\text { who have passed "Studieprøven" }\end{array}$ \\
\hline $\begin{array}{l}\text { Students not exposed to Danish } \\
\text { before entering the university }\end{array}$ & & $\begin{array}{l}\text { Full degree international students in } \\
\text { English-medium programs } \\
\text { Free movers } \\
\text { Exchange students }\end{array}$ \\
\hline
\end{tabular}

Table 1. Categories of multilingual students at Danish universities according to their exposure to Danish and their entrance exam

7 GIF refers to Gymnasialt Indslusningskursus for Flygtninge og indvandrere, directly translated into Introduction at high school level for refugees and immigrants. This is a one year remedial program supplementing a foreign entrance exam.

8 Studieprøven is a language proficiency test at $\mathrm{C} 1$ level which is a prerequisite for university students who are not full degree international students or exchange students and who have a foreign, non-Nordic, non-GIF entrance exam. 
By distinguishing between domestic and international students according to their entrance exam and not - as in the statistical information - their citizenship or ways of applying to get into a Danish university, the students' previous learning experience is seen as the most important dimension. Part of this is also the students' command of academic Danish. In general, this is seen as a requirement for all students except international students (full degree and exchange students) in English-medium programs. However, only international students with a background outside the Nordic countries have to document their Danish competence, e.g. by passing a Danish test ("Studieprøven"). Although the universities take in students with varying degrees of Danish competence, there is no tradition for the universities to offer classes in academic Danish. Councilors often refer international students to the state-supported adult education of basic Danish or to crash courses for exchange students. A survey in 2005 concluded that 9 out of the then 12 Danish universities ran courses in Danish, but only two of these had an academic content. Instead they focused on media, sports, shopping etc. suitable for newly arrived students on shorter terms, but not catering to the academic needs of full degree students in Danish-medium instruction or minority students (DMA research 2005). Despite increased focus on internationalization since 2005 (see the two governmental reports Enhanced Insight through Global Outloook from 2013 and Denmark. An attractive study destination from 2014) there has been little focus on academic Danish and more on initiatives taken to secure English-medium instruction. Apparently Van der Walt's warning also applies to Danish universities that "the danger for HEIs where internationalization is high on the institutional agenda could be that concerns about access to HE by minoritised students inside the country are overshadowed by discussions about how to increase access for transnationally mobile students" (Van der Walt 2013: 36).

\section{Categorizing minority students: Mainstream or special needs?}

Distinguishing between categories of students is institutionally important when the focus in on access to the universities and when measuring internationalization in terms of numbers. One example suffices: in its recent strategy Denmark. An attractive study destination (April 2014), the Danish government sets a target of raising the share of fee paying international students from 12 $\%$ till $20 \%$ of all international students by 2020 . This means $80 \%$ international students from the Nordic countries and EU, and $20 \%$ from the rest of the world. In the first part of this strategy (Enhanced Insight through Global Outlook, 2013), the government set up similar targets to promote exchange programs between universities in specific countries (more students from a European background because of Erasmus + , more students from outside English-speaking countries because of emergent economies). Both plans entail counting incoming students according to national background. Furthermore, students with different educational and linguistic background and different time spans for their stay in Denmark are bound to have different language needs in connection with both Danish-medium and English-medium instruction. This means that when planning appropriate language teaching for students, it is important to be able to distinguish between different groups of students according to their background and needs (Long 2005).

However, labeling different groups is also a sensitive issue. First of all, background labels do not always correspond with student behavior. When the students are present in the classrooms, they are there with other professional interests and individual identities than e.g. their nationality or time span in Denmark. In other words, their learning potential is more complex than their formal background. Secondly, there is a certain overlap between categories, e.g. in table 1, and individual students may even change formal status over time (e.g. exchange students becoming full degree students). Thirdly, categories are not always kept apart in the minds of staff and students9. This means that exchange students and international full degree students, but sometimes also do-

9 The observation that full degree students, exchange students and domestic minority students are often confused in the classrooms is based on a number of interviews with study board members and international coordinators across the University of Copenhagen during the first year of the language strategy More Languages for More Students. 
mestic minority students, are brought together into one category which is sometimes referred to as 'foreign', but which may also be seen as predominantly non-majority. What unites these students is mainly their affiliation with other languages than Danish or English, but they are also talked about in terms of differences in educational culture and learning styles (Rektorkollegiet 2001, DMA Research 2005, Pedersen 2006, Hauksdottir 2012).

However, the main problem with labeling minority students is the rejection of the labels from the students themselves. Specific labeling seems sensitive for all minority students, but it is most strongly opposed by domestic minority students with a Danish entrance exam who resist being identified as special and outside the mainstream student body. At least this is one way of interpreting the experience reported by the student from the School of Pharmaceutical Sciences in Copenhagen who is behind the title of this paper. After saying that "bilingual means foreigner" she adds:

\begin{abstract}
But there are many people who know more than one language. Danes also know English; this also applies to the Swedes who come here. But they are not seen as bilingual. ... It is different for the people who grew up here. I came when I was 21 so for me it is fine to be seen as bilingual. (Laursen 2013: 42-43, my translation).
\end{abstract}

When being bilingual refers to foreignness (and not to language use or competence), domestic students with minority background will defy being labelled that way and they will be hesitant to sign up for language courses which are specifically targeted at their needs for academic Danish ${ }^{10}$. For this reason, Centre of Internationalisation and Parallel Language Use at University of Copenhagen has recently changed its strategy concerning Danish classes for students from a specific focus on students with Danish as their second language towards a broader intake of students (majority and minority). Reports from several Danish universities confirm that there is a general stigma connected to receiving special treatment because of one's level of academic Danish and that students feel a lack of social prestige in being identified as "speakers of Danish as a second language" (Laursen 2003), "bilingual speakers" (Odgaard 2014, Lund/Bertelsen 2008), "foreign language speaking students" (Rektorkollegiet 2001) or "students with different ethnic and linguistic background" [than Danish] (Pedersen 2006).

However, language problems which are left unaddressed may be counterproductive in creating the active and responsible students which the universities aim at. This was expressed by a minority student in Aarhus when asked to elaborate on what it means to be kept back in his studies because of language:

\begin{abstract}
It means that you do not get the full outcome of a lecture. Language used for lectures differs from the everyday language of the street. But it also means that you have problems getting a study group. And that complicates everything. You dare not go to the blackboard. The problem is how to communicate. Bilingual students are more passive. And then you feel tempted to stay at home and you become less dedicated (Pedersen 2006: 53, my translation).
\end{abstract}

Like the student at the School of Pharmaceutical Sciences in Copenhagen, this student has moved to Denmark quite late and has entered the university with a foreign entrance exam and supplementary Danish courses. Maybe that makes him more outspoken and willing to share his situation with others, despite his report on being silent in class. Pedersen (2006) concludes that minority students who have arrived later are more prone to developing the language reflection which is crucial for their study-efficiency than the students who bring in their experience from Danish secondary education. She bases this on a number of interviews combined with a comparison between the two groups in terms of study efficiency (i.e. number of exams taken). The students who have arrived later considerably outperform the students with a Danish school background. Pedersen concludes that the study problems which the latter group of students are faced with "could very well be a consequence of low self-esteem developed in an educational system which focuses on

10 During the program Education at its Best in 2011-12, the Centre developed courses in academic Danish as a second language at two departments with a high proportion of domestic minority students. After the program ended, the departments are reluctant to designate specific courses to minority students. 
correct Danish" (Pedersen 2006: 79, my translation). She quotes a teacher from secondary school who says that "Unfortunately many of our students do not have a lot of school success in their background. They have learned to conceal their lack of competence and do not at all want to be confronted with this" (2006: 71, my translation). The underachievement of minority students in Danish primary and secondary education is well-documented (Holmen 2009, Danish Evaluation Institute 2006 and 2007, UNI-C 2009). However, there has been very little focus on the negative effect of producing passive and silent students for their post-secondary education.

The relative higher level of tolerance towards the Danish used by students with a non-Danish school background is not confirmed by Hauksdottir (2012) and Lund/Bertelsen (2008) whose informants report on a low linguistic tolerance towards 'broken Danish' among both their peer-students and teachers. Lund/Bertelsen even quote a former director of the study administration at University of Copenhagen for saying that "Danish students feel that life is too short for people who cannot express themselves [in Danish] (2008: 205). Maybe both groups of minority students experience a low level of linguistic tolerance, but the group with previous school experience in Denmark is not as willing to share this with outsiders. In an essay on her personal experience as a minority student in a Danish secondary classroom, El Mohbi (2002) confirms that minority students are met with educational measures based on what Pedersen refers to as "correct Danish". Apparently, this is a norm which takes middle class mother tongue proficiency for granted, with little effort to give minority students access to the norm through teaching practices which promote their language acquisition. El Mohbi does not suggest that language issues should be reduced in priority in secondary education; instead she argues that teaching practices should be informed by knowledge about second language use and the school situation for second language users. In her critique of main stream education for being blind towards the actual language needs and potentials of a diverse student group, El Mohbi and Pedersen (2006) are in line with the advocates for translanguaging or other kinds of multilingual education (Canagarajah 2011, Garcia 2009, Preece 2011, Hafernik/Wiant 2012).

\section{Conclusion: Dilemmas in categorizing students according to language}

With increased focus on student mobility there is also a change towards more English-medium instruction at Danish universities. This requires development of academic English in both domestic and international students. However, according to the students interviewed in e.g. Sanne Larsen's study (2013), there are several norms of academic English at play in Danish higher education, among them local norms of using English-as-lingua-franca in classrooms characterized by student diversity and with students and teachers with varying degrees of English language competence. The students see these classrooms as useful arenas for both content and language learning. At the same time there are initiatives taken towards establishing both new kinds of specific language courses and different forms of language-and-content-integrated learning (see pilot projects under More Languages for More Students at University of Copenhagen). Language plays an important role in this development, but without necessarily being followed by a return to native speaker norms or other excluding measures. The picture looks somewhat different with Danishmedium instruction. Here native speaker norms seem to be taken for granted, without the communicative pragmatics of the lingua franca atmosphere and without the awareness that there are students in the classroom who need to develop language and content simultaneously. Both international students and domestic minority students mention that this learning environment is problematic (Hauksdottir 2012, Lund/Bertelsen 2008, Pedersen 2006). They report on being silent in class, on withdrawing from group work - or not being invited in - and on not getting the feedback that they need in order to further their language competence. As one student said when interviewed by Pedersen (2006: 52): "Sometimes you feel that you are left to your own devices". Apparently, there is very little explicit focus on developing language use and language learning in Danish-medium instruction and therefore no guidance in how to approach the norms for academic Danish which are being followed anyway. One solution to this dilemma is to lower the standards 
for academic Danish when assessing minority students in classrooms and for exams. However, exercising that kind of repressive tolerance might be counterproductive and result in even more stigmatization of minority students during their studies and in the long run in weakening their chances at the academic labor market. A better - and more inclusive - solution would be to teach the norms of academic Danish which are functionally motivated, and to be explicit about the role of language in teaching and learning of any kind of content.

This paper has argued that the students' command of Danish is crucial when they are categorized according to their background, but also when they are categorized according to their academic learning needs. However, it seems that this language need is largely ignored in Danish higher education. According to the survey across 65 European universities carried out by Extra/ Yagmur (2012), Danish universities score high on internationalization parameters connected to English-medium instruction and student mobility, but they do not follow up by providing adequate language support in Danish. Furthermore, as $50 \%$ of the universities report in the survey, they do not make a conscious effort to recruit domestic minority students. It seems that Danish universities would profit from following the examples of some other European universities (e.g. the universities in Finland) and develop not only courses with a focus on students' academic English, but also on their academic Danish. However, as this paper has shown this is also a sensitive issue since domestic minority students may not be interested in being identified as a group with special language needs or targeted through a special recruitment campaign. It is suggested that their resistance towards being singled out stems from the learning environment they have experienced in secondary education, but it also affects their willingness to take part in classes at the university, even when they are offered tailor-made classes of academic Danish, based on what seems to be their actual needs. This is one of the dilemmas of categorizing students according to language needs.

Of course, the students in question may also have realized that short term remedial classes will not make them academically competent users of Danish. Maybe they see through what Hafernik/ Wiant (2012) call "the myth of transience", i.e. the idea that students' study problems can be fixed easily through language classes. Hafernik/Wiant argue that a much more complex approach is needed in order to transform higher education into more ambitious sites of learning. In their book which is directed towards faculty dealing with diverse student groups they go against compartmentalized courses and appeal to teachers to integrate language concerns in their general teaching and counseling activities. However, when focusing on the Danish situation and on Danish-medium instruction it becomes clear that there are obvious risks of negligence tied to mainstreaming minority students without changing the learning environment accordingly. This is a second dilemma connected to labeling - or rather to non-labeling of minority students.

Alternatively, the alleged new paradigm of multilingualism in higher education might bring about new labeling practices. Many students have linguistic resources tied to their competence in other languages which are not put actively into use in their academic life at Danish universities. To develop every student to his or her full potential through individualized academic learning trajectories is one of the more visionary parts of modern university teaching and learning thinking. For linguistic minority students this vision would profit from being combined with a multilingual approach which can draw on the linguistic resources of all students; indeed if Canagarajah (2011) is right about his skepticism about the reality of monolingualism, a multilingual approach to teaching and learning in higher education would be both meaningful and relevant to all students. This would entail identifying students not only through their command of Danish, but also through other languages. Eventually, it may even lead to a situation where attending Danish classes becomes more attractive because there are many other languages around to identify with for the students. 


\section{References}

Allerup, Peter 2004: Analyse af karakterer. In Saarup, Jens et al. (eds.), Evaluering af dansk som andetsprog i folkeskolen. København: CVU København og Nordsjælland, 117-120.

Blackledge, Adrian/Creese, Angela 2010: Multilingualism. A critical perspective. London: Continuum.

Blommaert, Jan/Rampton, Ben 2011: Language and Superdiversity. In Diversities, 13, 2, 1-21.

Boden, Rebecca/Wright, Susan 2010: Follow the money. An interim report on Danish University funding prepared for Dansk Magisterforening. Copenhagen: Dansk Magisterforening, web: January 6, 2010.

Canagarajah, Sunesh 2011: Translanguaging in the classroom. Emerging issues for research and pedagogy. In Applied Linguistics Review 2, 1-28.

Christensen, Vibeke Tornhøj et al. 2014: PISA Etnisk 2012. PISA 2012 med fokus på unge med indvandrerbaggrund. København: KORA.

Danish Government 2013a: Denmark 2020. Knowledge, growth, wealth, welfare [Danmark 2020. Viden, vækst, velstand, velfærd]. København: Regeringen.

Danish Government 2013b: Enhanced Insight through Global Outlook [Øget indsigt gennem globalt udsyn]. Copenhagen: Regeringen.

Danish Government 2014: Denmark. An Attractive Study Destination. København: Regeringen.

Danish Evaluation Institute [Danmarks Evalueringsinstitut] 2006: Gymnasiets tiltag for tosprogede elever.

Danish Evaluation Institute [Danmarks Evalueringsinstitut] 2007: Undervisning af tosprogede elever i folkeskolen.

Daryai-Hansen, Petra 2010: Repræsentationernes magt. Sproglige hierarkiseringer i Danmark. In Jørgensen, J. Normann/Holmen, Anne (red.), Sprogs status i Danmark 2021. Københavnerstudier i tosprogethed, 58, 87-105.

Delsing, Lars-Olof /Åkesson, Katarina Lundin 2005: Håller språket ihop i Norden? En forskningsrapport om ungdomars förståelse av danska, svenska och norska. Tema Nord 2005: 573, København: Nordisk Ministerråd.

DMA Research 2005: Mapping of Danish courses for foreign students at the universities [Kortlægning af universiteternes danskkurser for udenlandske studerende].

El-Mohbi, Hiba 2002: “Jeg virker nok bare dum”. In Dansknoter 1, 15-18.

Elsborg, Steen et al. 2005: Muligheder for mønsterbrud i ungdomsuddannelserne. Mønsterbryderprojektet, vol. 1-2, Odense: Syddansk Universitetsforlag.

Extra, Guus/Kutlay Yagmur (eds.) 2012: Language Rich Europe. Trends in policies and practices for multilingualism in Europe. Italy: Cambridge University Press.

Garcia, Ofelia 2009: Bilingual Education in the 21 $1^{\text {st }}$ Century. A Global Perspective. Oxford: Wiley-Blackwell.

Gregersen, Frans 2012: Globaliseringens udfordringer med særligt hensyn til universitetsinstitutionerne. Nordand. 2 , 7, 5-19.

Gregersen, Frans (red.) 2012:’Domænetab og parallelsproglighed på nordiske universiteter”. Temanummer af Nordand $7,2,2012$.

Gregersen, Frans (red.) 2014: Hvor parallelt. Om parallelspråkighet på Nordens universitet. TemaNord 2014. København: Nordisk Ministerråd.

Haberland, Hartmut/Risager, Karen 2008: Two pilot studies of multilingual competence in international programmes at Roskilde University. In Haberland et al. (eds.), Higher Education in the Global Village. Cultural and Linguistic Practices in the International University. Roskilde: Roskilde University, 41-65.

Hafernik, Johnnie Johnson/Wiant, Fredel M. 2012: Integrating Multilingual Students into College Classrooms. Practical Advice for Faculty. Bristol: Multilingual Matters.

Háuksdottir, Audur 2012: Dansk som nøglen til uddannelse. Københavnerstudier i tosprogethed. 68. København: Københavns Universitet.

Hoff, Jens William/Demitras, Mehmet 2009: Frafald blandt etniske minoritetsstuderende på universitetsuddannelser $i$ Danmark. København: Forlaget Politiske Studier.

Holmen, Anne 2009: Multilingualism in education. In favour of a dynamic view of languages. In Kjørven, Ole Kolbjørn et al. (eds.), Teacher Diversity in Diverse Schools. Challenges and Opportunities for Teacher Education. Vallset: Oplandske Bokforlag, 183-200.

Hultgren, Anna Kristina 2014: Parallelsproglighed på danske universiteter. En statusrapport 2013. In Gregersen, Frans (red.), Hvor parallelt. Om parallelspråkighet på Nordens universitet. TemaNord 2014, 117-196. København: Nordisk Ministerråd.

Ingerslev, Gitte Holten et al. (red.) 2013: Universitetspcedagogik. København: Samfundslitteratur. 
Jürna, Merike 2014: Linguistic realities at the University of Copenhagen. Parallel language use in practice as seen from the perspective of international staff. In Hultgren, Anna Kristina et al. (eds.), English in Nordic Universities. Ideologies and Practices. John Benjamins, 225-249.

Jørgensen, J. Normann 2008: Polylingual languaging around and among children and adolescents. In International Journal of Multilingualism, 5, 3, 161-176.

Kramsch, Claire 2009: The Multilingual Subject. What language learners say about their experience and why it matters. Oxford: Oxford University Press.

Kristjánsdóttir, Bergthóra 2011: Nysprog om tosprog. Sprogbrug, politik og pædagogik. In Haas, Claus et al., Ret til dansk. Uddannelse, sprog og kulturarv. Århus: Århus Universitetsforlag, 117-220.

Larsen, Sanne 2013: Re-contextualising academic writing in English. Case studies of international students in Denmark. PhD thesis, University of Copenhagen.

Laursen, Katja Årosin 2013: "Det er sprogligt. Selv hvor du ikke lagger mcerke til det”. En empirisk undersøgelse af sproglige og faglige vanskeligheder hos farmaceutstuderende med dansk som andetsprog på Københavns Universitet. Københavnerstudier i Tosprogethed, volume C4. København: Københavns Universitet.

Long, Michael H. 2005: Second Language Needs Analysis. Cambridge: Cambridge University Press.

Lund, Karen/Bertelsen, Ellen 2008: Fra Studieprøven til de videregående uddannelser. København: Ministeriet for Flygtninge, Indvandrere og Integration.

Magisterbladet 2014: Thematic issue on 'Kvalitetsudvalget', 4, 19. april 2014, 26-31.

Maton, Karl 2004: The wrong kind of knower. Education, expansion and the epistemic device. In Muller, Johan et al. (eds.), Reading Bernstein, Researching Bernstein. London: Routledge, 218-231.

Mortensen, Janus/Haberland, Hartmut 2012: English - the new Latin of academia? In International Sociology of Language 216, 175-197.

Odgaard, Stine Myssing 2014: "Det er ikke et sprog, man bare kan samle op på gaden”. En undersøgelse af behovet for kurser i akademisk dansk for studerende med dansk som andetsprog på Institut for Tværkulturelle og Regionale Studier på Københavns Universitet. Upubliceret speciale, Institut for Nordiske Studier og Sprogvidenskab, Københavns Universitet.

Pedersen, Anne Leth 2006: Studieeffektivitet og sproglige kompetencer. Støtte- og rådgivningscentret, Aarhus Universitet.

Preece, Sian 2011: Universities in the Anglophone centre: Sites of multilingualism. In Li Wei (ed.), Applied Linguistics Review. 2. Berlin. De Gruyter Mouton.

Preisler, Bent 2010: Engelsk og dansk. Funktioner og status - nu og i nærmeste fremtid. In Jørgensen, J. Normann/ Holmen, Anne (red.), Sprogs status i Danmark 2021. Københavnerstudier i tosprogethed, 58, 106-120.

Rektorkollegiet 2001: Integration af fremmedsprogede studerende på de lange videregående uddannelser.

Ruiz, Richard 1984: Orientations in Language Planning. In NABE Journal 8, 2, 15-34.

Shohamy, Elana 2006: Language Policy. Hidden Agendas and New Approaches. London: Routledge.

Sickinghe, Anne-Valérie 2013: The Discursive Construction of Multilinguals in Norwegian Language education Policy. In Nordand 8, 2, 87-114.

Spack, Ruth 1997: The Rhetorical Construction of Multilingual Students. In TESOL Quarterly 31, 4, 765-779.

Tange, Hanne 2012: Wars of Words. Management Policy and Employee Practice at the International University. In Tamara 10, 4, 1-24.

UNI-C 2009: Frafald på de gymnasiale uddannelser. Hanne Bech og UNI-C Statistik og analyse.

University of Copenhagen 2012: Mapping of educational internationalization [Kortlægning af internationalisering af uddannelser] Report from the International Office, Copenhagen.

University of Copenhagen 2014: More Languages for More Students [online]. http://cip.ku.dk/english/strategicinitiatives/languagestrategy/

Van der Walt, Christa 2013: Multilingual Higher Education. Beyond English Medium Orientations. Bristol: Multilingual Matters.

van Leeuwen, Charles 2004: Multilingual Universities in Europe: models and realities. In Wilkinson, Robert (ed.), Integrating Content and Language: Meeting the challenge of a Multilingual Higher Education. Maastricht, 576-584. 